6. Kontseptsiia rozvytku hromadianskoi osvity v Ukraini. URL: https://mon.gov.ua/.../2018/../1kontseptsiya-rozvitku-gromosviti-v-ukraini-1701201/ (data zvernennia: 04.02.2019).

7. Pro proekt "Zhyvemo v demokratii". URL: https://www.living-democracy.com.ua/ (data zvernennia: 27.03 .2018 ).

8. Ia u sviti. Navchalna prohrama dlia zahalnoosvitnikh navchalnykh zakladiv $3-4$ klasy (onovleno). URL: http://mon.gov.ua/activity/education/zagalna-serednya/pochatkova-shkola.htm/ (data zvernennia: 1.09.2019).

Одержано статтю: 6.02 .2019

Прийнято до друку: 20.03.2019

УДК 377/3:338.488.2:640.41] :

$005.336 .2-027.56$

DOI: $10.15330 /$ esu. $15.87-96$
Андрій Козак,

директор, Бурштинський торговельноекономічний коледж Київського національного торговельно-економічного університету, аспірант, Інститут професійно-технічної освіти НАПН України (м. Бурштин, Україна)

Andriy Kozak,

Director, Burshtyn college of trade and economics of Kyiv national university of trade and economics, Post-graduate student, Institute of vocational education and training of NAES of Ukraine (Burshtyn, Ukraine)

btekknteu@ukr.net

\title{
МОДЕЛЬ ФОРМУВАННЯ ПРОФЕСІЙНОЇ КОМПЕТЕНТНОСТІ МАЙБУТНІХ МАЙСТРІВ РЕСТОРАННОГО ОБСЛУГОВУВАННЯ У ПРОФЕСІЙНО- ПРАКТИЧНІЙ ПІДГОТОВЦІ
}

\section{MODEL OF PROFESSIONAL COMPETENCE FORMING FOR FUTURE RESTAURANT SERVICE MASTERS' PROFESSIONAL APPLIED TRAINING}

Інновачійний розвиток сфери ресторанного господарства зумовлюс поиук нових форм, методів, способів професійної підготовки майбутніх фахівців у закладах професійної (професійно-технічної) освіти та систематизованої репрезентачії досвіду організачії прочесу формування професійної компетентності майбутніх майстрів ресторанного обслуговування у вигляді педагогічних моделей. На основі результатів аналізу педагогічних моделей формування відповідних знань, умінь та навичок майбутніх фахівиів з'ясовано, ио основою їх розроблення є сучасні методологічні підходи (компетентнісний, системний, суб'сктний, особистісно-розвивальний, контекстний, діяльнісний), як визначальні оріснтирри досягнення якості професійної підготовки. У статті схарактеризовано складники моделі формування професійной компетентності майбутніх майстрів ресторанного обслуговування, а саме: чільовий, змістовий, прочесуально-методичний, діагностично-результативний блоки. Узагальнено, що упровадження моделі формування професійної компетентності майбутніх майстрів ресторанного обслуговування у професійно-практичній підготовиі передбачає дотримання та реалізацію зв'язків між наявними нормами організації професійної підготовки майбутніх майстрів ресторанного обслуговування та сучасними вимогами ресторанної індустрії з орієнтацією на формування професійно компетентного майбутнього фахівчя - здатного ефективно провадити професійну діяльність у динамічно змінних умовах розвитку ресторанного господарства.

Ключові слова: професійна (професійно-технічна) освіта, професійно-практична підготовка, професійна компетентність, майбутні майстри ресторанного обслуговування, метод моделювання, сфера ресторанного господарства. 
Innovative development of restaurant service sector gives rise to searching new forms, methods, ways for professional training the future specialists in professional (vocational) education and system-based demonstration of organizational experience for future professional restaurant service masters' training in the form of pedagogical models. Based on analysis results of pedagogical models for forming appropriate knowledge and skills for future professionals it is found that modern methodological approaches (competence, system, subject, person-developing, context, activity - based) are laid in their essence as defining benchmarks for getting the quality of professional training. The article represents characteristics of professional competence forming model for future restaurant service masters, in particular: purpose (aim, approaches and principles), content (structure and content of future restaurant service professionals' professional competence), process-methodological (methodology of forming the professional competence of future restaurant service professionals and applied training methods for realization pedagogical conditions), diagnostic-result based (criteria, indicators and formation levels of studied phenomenon).

It generalises the implementation of professional competence forming model for future restaurant service masters professional training and foresees links compliance and implementation between present norm of professional training organization for future restaurant service masters and modern demands of restaurant industry oriented on forming future professionals' professional competence able to provide professional activity in efficient way under dynamic changing conditions for restaurant sector development.

Key words: professional (vocational) education, professionally-applied training, professional competence, future restaurant service masters, modelling method, restaurant service sector.

Постановка проблеми. Трансформація традиційних форм, методів, способів професійної підготовки майбутніх фахівців у закладах професійної (професійнотехнічноі) освіти (далі - ЗП(ПТ)О) відповідно до сучасних реформ в освіті та 3 орієнтацією на виробничі інновації у галузі веде за собою видозміну функціонування окремих елементів педагогічних систем, зумовлюючи відповідні модифікації й у процесі здійснення професійно-практичної підготовки. Характерною ознакою модернізації освітньої галузі, на переконання Л. Руденко, $\epsilon$ використання методу моделювання як найбільш адекватного способу, пошуку оптимального вирішення поставлених завдань, оскільки він дає змогу відтворити цілісність об'єкту та спрогнозувати його перспективи. Взаємозв'язок педагогічної науки i практики, який сприяє розширенню культурно-освітнього простору та поглибленню його змісту, свідчить про актуальність цього методу і необхідність його впровадження в педагогічний процес [11, с. 197].

Аналіз останніх досліджень і публікацій. Звертаючись до наукових джерел iз питань педагогічної освіти відслідковуємо, що у площині педагогічних процесів модель є специфічним об'єктом, що створений 3 метою отримання або збереження інформації, що відображає властивості та характеристики його зв'язку із суб'єктом. Структурні елементи моделі мають відображати зв'язок педагогічної науки 3 практикою [9, с. 153]. У площині наукових досліджень Ю. Сурміним сформульовані необхідні і достатні ознаки моделі, а саме: між моделлю і оригіналом існує відношення схожості, форма якого явно виражена і точно зафіксована (умови віддзеркалення, або уточнення, аналогіi); модель в процесі наукового пізнання $є$ заміщенням об'єкта вивчення (умова репрезентації); вивчення моделі дає змогу отримати інформацію (відомості) про оригінал (умови екстраполяціі) [12, с. 138139]. За допомогою моделі, як знаковою системи, можна відтворити дидактичний процес як предмет дослідження, показати в цілісності його структуру, функціо- 
нування і зберегти цю цілісність на всіх етапах дослідження, - обгрунтовує В. Ягупов [13, с. 31]. У процесі моделювання С. Гончаренко визначає такі етапи: перехід від природного об'єкта до моделі, побудова моделі, експериментальне дослідження моделі, перехід від моделі до природного об'єкта (перенесення результатів, отриманих в ході дослідження, на даний предмет) [3, с. 120]. У розробленні педагогічних моделей, на думку А. Ашерова, визначальними мають бути такі орієнтири: процес підготовки, навчальна діяльність, майбутня професійна діяльність фахівця [1].

Таким чином, на основі результатів аналізу окремих визначень науковців щодо сутності й призначення методу моделювання узагальнюємо, що у наукових педагогічних дослідженнях створення моделі формування певного явища передбачає конструкцію (проектування) педагогічного процесу (чи його окремої складової, наприклад, професійно-практичної підготовки), у якій, за допомогою схематизації, ми відображаємо компоненти (елементи) досвіду 3 проблеми дослідження i в результаті отримуємо систематизовану репрезентацію цього досвіду, як засіб для пояснення й використання у педагогічній практиці.

Мета статті - обгрунтувати модель формування професійної компетентності майбутніх майстрів ресторанного господарства в процесі професійнопрактичної підготовки.

Виклад основного матеріалу. Для розроблення моделі формування професійної компетентності майбутніх майстрів ресторанного обслуговування (далі MPO) у процесі професійно-практичної підготовки суттєвою є орієнтація на аналіз тих моделей, які відображають власне процес формування професійної компетентності, що відбувається у ході здійснення професійної підготовки (професійно-теоретичної чи професійно-практичної), а також тих наукових досліджень, у яких змодельовано розвиток чи формування певних якостей у майбутніх фахівців сфери послуг.

До прикладу, О. Загіка розглядає модель формування професійної компетентності у майбутніх агентів з постачання у ЗП(ПТ)О “як інтегративну систему, що об'єднує в єдину цілісність мету, зміст, дидактичний комплекс (принципи, педагогічні умови, завдання, методи, прийоми засоби, освітнє середовище) та результат навчально-виховного процесу, забезпечує формування в учнів системи фахових знань, умінь, навичок, готовності до професійного виконання функціональних обов'язків на робочому місці". Основними структурними елементами моделі автор визначає: цільовий, змістовий, організаційно-технологічний, діагностично-результативний блоки [4, с. 100-104]. Модель формування ключових компетентностей майбутніх фахівців ресторанного сервісу, представлена С. Кравець, є цілісною системою, що реалізовується відповідно до взаємозв'язаних компонентів: цільового, змістового, суб'єктного, технологічного, оцінно-результативного [6, c. 107]. Варто звернути увагу на процедурність створення й функціональне призначення педагогічної моделі формування економічної компетентності майбутніх фахівців готельного та ресторанного сервісу, розроблену О. Богоніс. Означена модель $є$ підсистемою, яка природно інтегрується у педагогічну цілісність, послідовно відтворює об'єкт і предмет дослідження й шляхом комплексного функціонування цільового, суб'єктного, змістово-процесуального i результативного блоків забезпечує упровадження методики реалізації педагогічних умов розвитку досліджуваного явища, спрямованої на досягнення майбутніми фахівцями ефективного результату при вирішенні економічних завдань у сфері індустрії гостинності. Доцільно зазначити, що одним із завдань реалізації цієї моделі є досягнення взаємовідповідності між вимогами індустрії гостинності до 
рівня сформованості економічної компетентності фахівців й показниками сформованості досліджуваної компетентності, виражених результатами навчання молодших спеціалістів готельного та ресторанного сервісу у коледжах [2, с. 124].

Особливості формування професійної компетентності майбутніх фахівців саме в умовах виробничого навчання і практики представлені у дисертаційних працях О. Марковської, О. Слободяника, О. Стечкевича та ін. Доцільно узагальнити, що у моделях формування досліджуваних явищ у процесі практичної підготовки, науковці грунтуються на ідеях компетентнісного підходу, визначаючи зміст компонентів моделей у контексті досягнення високого рівня сформованості професійної компетентності майбутніх фахівців засобами сучасних педагогічних інновацій та відповідно до тенденцій розвитку технологій виробництва. Безперечно, зміни акцентів на отримання нових результатів професійної (професійнотехнічної) освіти актуалізують значущість компетентнісного підходу до забезпечення якості підготовки кваліфікованих робітників, спрямованого на розвиток особистості професіонала 3 позитивним світоглядом, ціннісними орієнтаціями, здатністю швидко адаптуватися до традиційних і непередбачуваних життєвих та професійних ситуацій. Як зазначає В. Радкевич, під компетентнісним підходом необхідно розуміти метод моделювання результатів професійно-технічної освіти, їх представлення у вигляді норм якості підготовки кваліфікованих робітників [10, с. 12].

Ми безперечно погоджуємось із тим, що сучасні моделі формування професійної компетентності майбутніх фахівців мають бути орієнтовані на досягнення норм якості професійної підготовки та співвідноситись із тенденціями розвитку виробництва у вітчизняній економіці. Інноваційний поступ ресторанного бізнесу “стимулює" пошук нових педагогічних форм, методів, технологій навчання, які безумовно мають знайти своє віддзеркалення у педагогічній моделі формування професійної компетентності майбутніх МРО. Власний управлінський та педагогічний досвід засвідчує, що організація та зміст професійно-практичної підготовки май бутніх МРО не у повній мірі співвідносяться із актуальними практичними уміннями, необхідними для професійної діяльності у сфері обслуговування, яка $\epsilon$ прогресивною галуззю економіки й характеризується на часі переходом на нові технології.

У цьому контексті О. Матвієнко розмірковує, що виявлені у ході дослідження потреби й суперечності є одним із джерел інноваційних процесів у розробленні сучасних моделей підготовки спеціаліста для тих сфер діяльності, які трансформуються на вимогу часу [7]. У підтвердження думки актуальними є роздуми академіка Н. Ничкало, яка стверджує: “саме в інноваційній діяльності народжуються нові моделі, педагогічні проекти, педагогічні технології, спрямовані на підвищення якості навчально-виробничого процесу і всієї освітньо-виховної роботи" [8, с. 176].

Таким чином, на основі результатів аналізу педагогічних моделей, спрямованих на формування відповідних знань, умінь та навичок майбутніх фахівців, зокрема у процесі професійно-практичної підготовки, ми узагальнюємо, що модель формування професійної компетентності майбутніх MPO у процесі професійно-практичної підготовки має грунтуватися на основних ідеях компетентнісного підходу, як визначального орієнтиру у досягненні якості професійної підготовки майбутніх фахівців.

Окрім того, модель формування професійної компетентності майбутніх МРО має відображати зв'язки між компонентами професійної компетентності майбутніх фахівців та спроектованими способами організації професійно-практичної підготовки, орієнтованої на удосконалення виробничого навчання й виробничої практики шляхом упровадження сукупності педагогічно-доцільних дидактичних методів, прийомів, 
засобів та організаційних форм навчання у спеціально створених педагогічних умовах організації цих процесів. Таким чином, відслідковуємо основні ознаки системного nідходу до розроблення моделі, якими є: універсальність (інтегрує у єдину систему елементи (компоненти) моделі, які перебувають у певній взаємодіï); ієрархічність (модель формування професійної компетентності майбутніх майстрів ресторанного обслуговування $\epsilon$ відносно самостійна зі своїми особливостями функціонування i розвитку, однак співвідноситься із принципами діючих освітніх систем); прогностичність (передбачення результатів упровадження моделі шляхом систематизації наявної інформації про досліджуване явище, коригування процесу його формування, перевірки нових даних щодо розвитку феномену й формулювання у цьому контексті системних ідей для перспективної реалізації створених підсистем цілісної освітньої системи).

Реалізація сучасних освітніх моделей, орієнтованих утвердження суб'єкта в професійної діяльності, актуалізує зміну акцентів освітніх впливів на учнів: із традиційного його сприймання як об’єкта навчання, до “...становлення учня суб'єктом учіння, суб'єктом навчальної діяльності, суб'єктом процесу навчання, що йому забезпечує становлення суб'єктом професійної діяльності, а в майбутньому успішну самоосвіту, професійне вдосконалення" [14, с. 31]. У такому разі взаємодія між учасниками освітнього процесу (викладачі, майстри виробничого навчання, учні) має грунтуватися на концептуальних ідеях суб'єктного підходу, забезпечуючи реалізацію таких функцій: розвиток учня як суб'єкта навчальної, а згодом i професійної діяльності; формування творчого суб'єкта професійної діяльності, здатного вчитися упродовж життя; підтримку і розвиток професійної мотивації, знаходження смислу соціального та професійного буття та його сприйняття; становлення учня як суб'єкта у системі міжособистісних відносин у середовищі закладу професійної освіти та у взаємодії з іншими людьми.

Результати суб'єкт-суб'єктної взаємодії між учасниками навчання логічно відображаються в організації професійно-практичної підготовки учнів на основі особистісно-розвивального підходу - як цілеспрямованого формування та розвитку особистості учня, розкриття його багатогранних здібкою мірою продуктивності у навчальній та професійній діяльності. Особистісно-розвивальний підхід передбачає визначення діяльності педагога й учня в їх взаємодії 3 дотриманням соціальної лінії, що відповідає сучасним умовам виховання та принципам демократичного суспільства; психолого-педагогічного супроводу, що передбачає реалізацію принципів індивідуалізації та диференціаціі, урахування психологічних особливостей кожного учня чи групи учнів; спрямування навчальної діяльності на особистісне зростання учнів як у освітньому середовищі, так і формування здатності до системного особистісного розвитку упродовж життя відповідно до професійної спрямованості. У такому разі актуалізується значення контекстного підходу, значення якого у моделі формування професійної компетентності майбутніх МРО полягає у досягненні ії мети у процесі професійно-практичної підготовки. У ході виробничого навчання i практики професійні функщії майбутнього фаху проектуються професійними знаннями, вміннями та навичками, які необхідні майбутньому фахівцю для успішної професійної діяльності. При цьому варто враховувати особливості й специфіку галузі, ресурсний потенціал регіону тощо й формувати професійні навички в учнів 3 огляду на соціально-економічні чинники розвитку індустрії гостинності. Контекстний підхід зорієнтований на практичну діяльність учнів, тому передбачає наповнення професійно-практичної підготовки діяльнісним змістом й застосування при формуванні 
професійної компетентності майбутніх МРО основних положень діяльнісного підлоду. Діяльнісний підхід у моделі формування професійної компетентності майбутніх майстрів ресторанного обслуговування інтегрує сукупність двох видів діяльності, а саме: навчальну та професійну. Навчальна діяльність передбачає опанування учнями теоретичними знаннями, дієвість яких проявляється у розв'язанні реальних практикних завдань у процесі здобуття професії, а згодом - при здійсненні професійних дій, трудових функцій. Йдеться про те, що навчальна діяльність поступово трансформується у професійно-практичну діяльність, а знання виступають засобами цісї діяльності. Якісно новими засобами трансформації навчальної діяльності у професійну в умовах ЗП(ПТ)О є сучасні інноваційні педагогічні технології, методичний потенціал яких скоординовує навчальний процес на поєднання теорії і практики, забезпечує зв'язок навчання із життям, дає змогу проектувати професійну підготовку відповідно до потреб ринку праці, в умовах, наближених до виробництва (виробниче навчання) або безпосередньо на виробництві (виробнича практика).

Таким чином, модель формування професійної компетентності майбутніх МРО у професійно-практичній підготовці (рис. 1) грунтується на основних ідеях компетентнісного, системного, суб'єктного, особистісно-розвивального, контекстного та діяльнісного підходів, які у поєднанні із загальнодидактичними та інноваційними принципами (науковості та доступності, систематичності й послідовності, наочності, зв'язку теорії з практикою, індивідуалізації, диференціації, інноваційності, інтегративності, соціального партнерства) формують цільовий блок. У площині суб'єктної взаємодії між учнями та педагогами (майстрами виробничого навчання) представляємо змістовий блок - структура та зміст професійної компетентності майбутніх MPO. На основі результатів аналізу системоутворюючих понять компетентнісного піходу узагальнено, що професійна компетентність майбутніх МРО є динамічною категорією, що проявляється здатністю особистості здійснювати навчально-виробничу діяльність у процесі навчання у закладах професійної (професійно-технічної) освіти та за умов позитивного подальшого розвитку ціннісно-мотиваційного, когнітивно-інноваційного, професійно-діяльнісного та особистісно-рефлексивного компонентів забезпечує кваліфікованим робітникам успішну соціалізацію та ефективне виконання ними професійних функцій у сфері ресторанного господарства [5, с. 92].

Процесуально-методичний блок моделі відображає етапи організації професійнопрактичної підготовки шляхом упровадження методики формування професійної компетентності майбутніх МРО, яка інтегрує практико-орієнтовані прийоми навчання й спрямована на реалізацію педагогічних умов. Зазначимо, що у процесі професійнопрактичної підготовки майбутніх МРО визначені нами педагогічні умови (підвищення мотивації учнів до набуття фахових знань, умінь та навичок; оновлення змісту професійного навчання 3 урахуванням сучасних виробничих тех.нологій ресторанної індустрії; здійснення професійного навчання на основі проектних технологій; використання інтегративного навчально-методичного комплексу формування професійної компетентності майбутніх МРО) реалізовуються на основі урахування особливостей функціонування цілісної системи професійної освіти та шляхом упровадження ціннісно-мотиваційного, пізнавально-творчого, когнітивно-діяльнісного, рефлексивно-результативного етапів методики. Застосування індивідуальних (бесіди, консультації) та групових (уроки виробничого навчання, виробнича практика, позаурочна робота та ін.) форм роботи, використання традиційних, інтерактивних (ділові, рольові ігри, ситуативні вправи, метод проектів, робота в малих групах, кейсметод та ін.) методів та інноваційних педагогічних технологій навчання у поєднанні із сучасними засобами навчання - комплексно забезпечують відтворення взаємозв'язків між компонентами моделі й спрямовані на формування структурних компонентів професійної компетентності майбутніх МРО. 


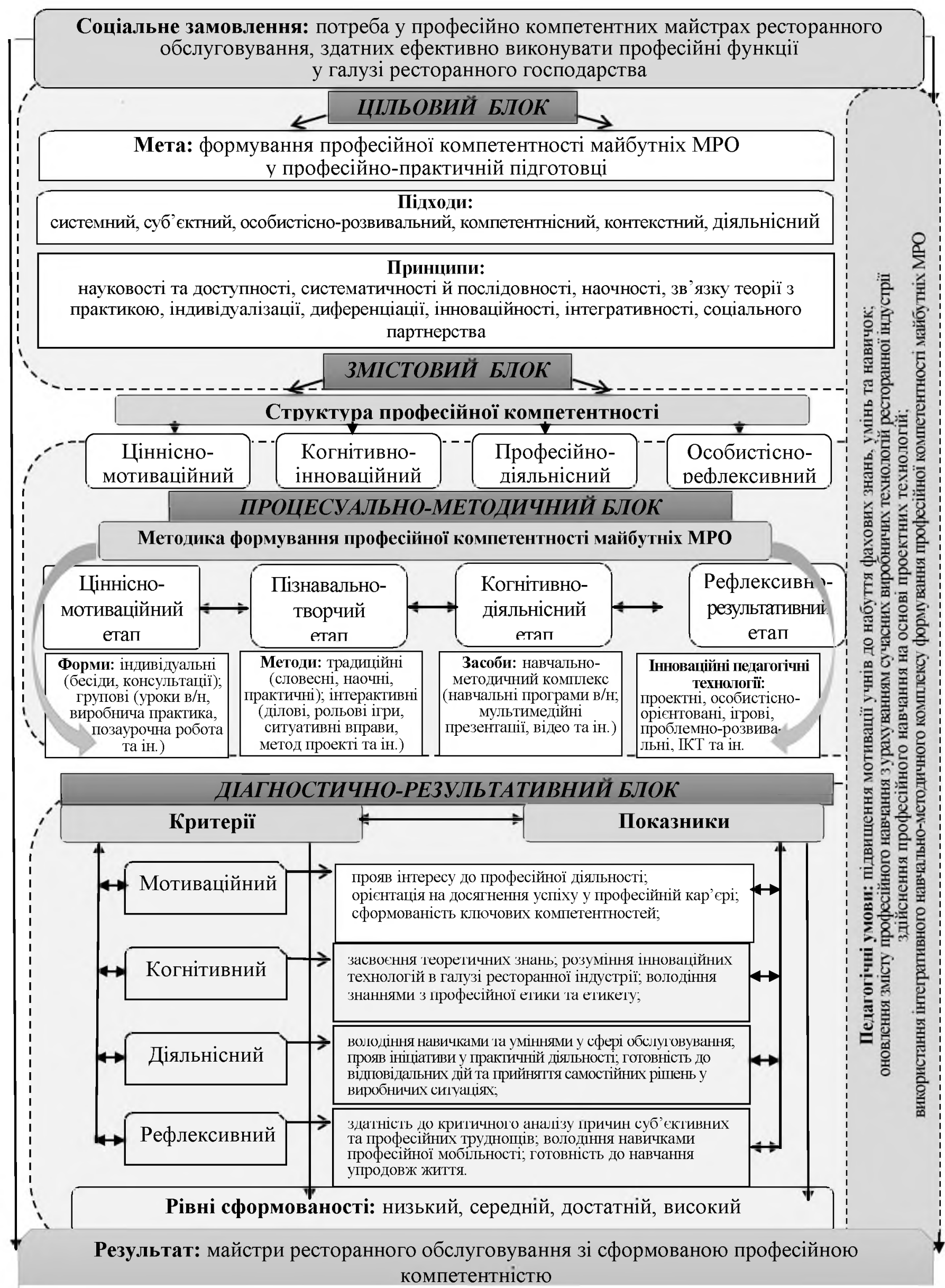

Рис. 1. Модель формування професійної компетентності майбутніх МРО у професійнопрактичній підготовці 
Для перевірки ефективності моделі уточнюємо діагностично-результативний блок, що репрезентує оцінювання динаміки рівнів сформованості професійної компетентності майбутніх МРО на основі критеріального апарату, а саме: мотиваційний критерій (прояв інтересу до професійної діяльності, орієнтація на досягнення успіху у професійній кар'єрі, сформованість ключових компетентностей); когнітивний (засвоєння теоретичних знань, розуміння інноваційних технологгій в галузі ресторанної індустрії, володіння знаннями 3 професійної етики та етикету); діяльнісний (володіння навичками та уміннями у сфері обслуговування, прояв ініціативи у практичній діяльності, готовність до відповідальних дій та прийняття самостійних рішень у виробничих ситуаціях); рефлексивний (здатність до критичного аналізу причин суб'єктивних та професійних труднощів, володіння навичками професійної мобільності, готовність до навчання упродовж життя).

Висновки. Практичне упровадження моделі формування професійної компетентності майбутніх майстрів ресторанного обслуговування у професійно-практичній підготовці на основі обгрунтованих ії складників передбачає дотримання та реалізацію зв'язків між наявними нормами організації професійної підготовки майбутніх майстрів ресторанного обслуговування та сучасними вимогами ресторанної індустрії 3 орієнтацією на формування професійно компетентного май бутнього фахівця здатного ефективно провадити професійну діяльність у динамічно змінних умовах розвитку ресторанного господарства. Відтак, ці зв'язки мають забезпечити:

1) відповідність процесу формування професійної компетентності майбутніх МРО в процесі професійно-практичної підготовки нормативно-правовим вимогам, що регламентують функціонування системи професійної освіти, організацію професійної підготовки, організацію навчально-виробничого процесу. У цьому контексті йдеться про урахування положень Конституції України, Національної рамки кваліфікацій (2011), Закону України "Про освіту" (2017), Закону України "Про професійно-технічну освіту" (1998), Наказу МОН України "Про затвердження Положення про організацію навчально-виробничого процесу у професійно-технічних навчальних закладах" (2006), Державного стандарту професійно-технічної освіти з професії "Майстер ресторанного обслуговування" (2013) та ін.

2) формування професійної компетентності майбутніх МРО 3 орієнтацією на тенденції науково-технічного прогресу, інноваційний розвиток високотехнологічного виробництва, узгоджуючи зміст освіти із сучасними вимогами ресторанної індустрії;

3) задоволення особистісних i професійних потреб майбутніх фахівців у реалізації індивідуально освітньої траєкторії на основі реалізації практикоорієнтованого компетентнісного підходу у процесі навчання.

Перспективні напрями дослідження пов'язуємо із детальним аналізом процесуально-методичного блоку моделі, що передбачає обгрунтування методики формування професійної компетентності майбутніх майстрів ресторанного обслуговування та добір доцільних педагогічних форм, методів, засобів та технологій іiі упровадження у процес професійно-практичної підготовки.

\section{Література}

1. Ашеров А. Т. Методы и модели обучения студентов компьютерных специальностей эргономической экспертизе трудовой среды / А. Т. Ашеров, В. В. Малёванная. - Харьков: НТМП, 2009. - $152 \mathrm{c}$.

2. Богоніс О. М. Формування економічної компетентності майбутніх молодших спеціалістів готельного та ресторанного сервісу у професійному коледжі : дис. ... канд. пед. наук : 13.00.04 / Богоніс Ольга Миколаївна ; Ін-т освіти і освіти дорослих НАПН України. - К., 2018. $-320 \mathrm{c}$. 
3. Гончаренко С. У. Педагогічні дослідження: методологічні поради молодим науковцям. Київ-Вінниця: ДОВ "Вінниця", 2008. - 278 с.

4. Загіка О.О. Формування професійної компетентності майбутніх агентів 3 постачання в професійно-технічних навчальних закладах: дис. ... канд. пед. наук : 13.00 .04 / Загіка Олена Олегівна ; Ін-т проф.-техн. освіти НАПН України. - К., 2015. - 270 с.

5. Козак А. Р. Сучасна структура професійної компетентності майбутніх майстрів ресторанного обслуговування / А. Р. Козак // Науковий вісник Інституту професійно-технічної освіти НАПН України. Професійна педагогіка : зб. наук. праць : Вип. 14 / Інст-т проф.-тех. освіти НАПН України ; [Ред. кол.: В. О. Радкевич (голова) та ін.]. - Вид. Свенок О. О., 2017. - С. $86-93$

6. Кравець С. Г. Формування ключових компетентностей у процесі професійної підготовки майбутніх фахівців ресторанного сервісу: результати педагогічного експерименту / / С. Г. Кравець // Професійна освіта: проблеми і перспективи / ППТО НАПН України. - К. : ППТО НАПН України, 2014. - С. 105-110.

7. Матвієнко О.В. Створення моделі спеціаліста на засадах теорії освітньої інноватики / О. В. Матвіснко // Педагогіка і психологія. - 2004. - №3. - С. 44-52.

8. Ничкало Н. Г. Трансформація професійно-технічної освіти України : монографія / Н. Г. Ничкало. - К. : Пед. думка, 2008. - 200 с.

9. Педагогічна освіта: теорія і практика. Педагогіка. Психологія : зб. наук. пр. / [редкол.: В. О. Огнев'юк та ін.] ; Київ. ун-т ім. Б. Грінченка, Ін-т пробл. виховання НАПН України. - К., 2008. - № 9. - C. 152-157.

10. Радкевич В. О. Компетентнісний підхід до забезпечення якості професійної освіти і навчання / Валентина Радкевич // Науково-методичне забезпечення професійної освіти і навчання : матеріали Всеукр. (звіт.) наук.-практ. конф. [23 березня 2012 р., м. Київ], Ін-т проф.-тех. освіти НАПН України [за заг. ред.. В. О. Радкевич]. - К., 2012. - Вип. 1. - С. 9-15.

11. Руденко Л. А. Формування комунікативної культури майбутніх фахівців сфери обслуговування у професійно-технічних навчальних закладах : монографія / Лариса Анатоліївна Руденко. - Львів : Піраміда, 2015. - 342 с. - Бібліогр. : с. 298-340.

12. Сурмін Ю. П. Майстерня вченого: Підручник для науковця. - К.: Навчально-методичний центр "Консорціум з удосконалення менеджмент-освіти в Україні", 2006. - 302 с.

13. Ягупов В. В. Моделювання навчального процесу як педагогічна проблема / В. В. Ягупов // Неперервна професійна освіта: теорія і практика : наук. метод. журн. / [голов. ред. С. Сисоєва]. - К., 2003. - Вип. 1. - С. 28-36.

14. Ягупов В. В. Суб'єктність учнів як основна детермінанта дистанційного навчання в системі професійно-технічної освіти / В. В. Ягупов // Наук. вісник Ін-ту проф.-тех. освіти НАПН України. Професійна педагогіка : зб. наук. праць : Вип. 11 / Інст-т проф.-тех. освіти НАПН України ; [Ред. кол. В. О. Радкевич (голова) та ін.]. - К. : Міленіум, 2016. - С. 29-37.

\section{References}

1. Asherov A. T. Metody i modely obuchenyia studentov kompiuternykh spetsyalnostei erhonomycheskoi ekspertyze trudovoi sredy / A. T. Asherov, V. V. Malëvannaia. - Kharkov: NTMP, 2009. - $152 \mathrm{~s}$.

2. Bohonis O. M. Formuvannia ekonomichnoi kompetentnosti maibutnikh molodshykh spetsialistiv hotelnoho ta restorannoho servisu u profesiinomu koledzhi : dys. ... kand. ped. nauk : 13.00.04 / Bohonis Olha Mykolaivna ; In-t osvity i osvity doroslykh NAPN Ukrainy. - K., 2018. - 320 s.

3. Honcharenko S.U. Pedahohichni doslidzhennia: metodolohichni porady molodym naukovtsiam. Kyiv-Vinnytsia: DOV "Vinnytsia", 2008. - 278 s.

4. Zahika O. O. Formuvannia profesiinoi kompetentnosti maibutnikh ahentiv $\mathrm{z}$ postachannia $\mathrm{v}$ profesiino-tekhnichnykh navchalnykh zakladakh: dys. ... kand. ped. nauk : 13.00.04 / Zahika Olena Olehivna ; In-t prof.-tekhn. osvity NAPN Ukrainy. - K., 2015. - $270 \mathrm{~s}$.

5. Kozak A. R. Suchasna struktura profesiinoi kompetentnosti maibutnikh maistriv restorannoho obsluhovuvannia / A. R. Kozak // Naukovyi visnyk Instytutu profesiino-tekhnichnoi osvity NAPN Ukrainy. Profesiina pedahohika : zb. nauk. prats : Vyp. 14 / Inst-t prof.-tekh. osvity NAPN Ukrainy ; [Red. kol.: V. O. Radkevych (holova) ta in.]. - Vyd. Yevenok O. O., 2017. - S. 86-93.

6. Kravets S. H. Formuvannia kliuchovykh kompetentnostei u protsesi profesiinoi pidhotovky maibutnikh fakhivtsiv restorannoho servisu: rezultaty pedahohichnoho eksperymentu / / S. H. Kravets // Profesiina osvita: problemy i perspektyvy / IPTO NAPN Ukrainy. - K. : IPTO NAPN Ukrainy, 2014. - S. 105-110. 
7. Matviienko O. V. Stvorennia modeli spetsialista na zasadakh teorii osvitnoi innovatyky / O. V. Matviienko // Pedahohika i psykholohiia. - 2004. - №3. - S. 44-52.

8. Nychkalo N. H. Transformatsiia profesiino-tekhnichnoi osvity Ukrainy : monohrafiia / N. H. Nychkalo. - K. : Ped. dumka, 2008. - 200 s.

9. Pedahohichna osvita: teoriia i praktyka. Pedahohika. Psykholohiia : zb. nauk. pr. / [redkol.: V. O. Ohnev'iuk ta in.] ; Kyiv. un-t im. B. Hrinchenka, In-t probl. vykhovannia NAPN Ukrainy. K., 2008. - № 9. - S. 152-157.

10. Radkevych V. O. Kompetentnisnyi pidkhid do zabezpechennia yakosti profesiinoi osvity i navchannia / Valentyna Radkevych // Naukovo-metodychne zabezpechennia profesiinoi osvity i navchannia : materialy Vseukr. (zvit.) nauk. -prakt. konf. [23 bereznia 2012 r., m. Kyiv], In-t prof.tekh. osvity NAPN Ukrainy [za zah. red.. V. O. Radkevych]. - K., 2012. - Vyp. 1. - S. 9-15.

11. Rudenko L. A. Formuvannia komunikatyvnoi kultury maibutnikh fakhivtsiv sfery obsluhovuvannia u profesiino-tekhnichnykh navchalnykh zakladakh : monohrafiia / Larysa Anatoliivna Rudenko. Lviv : Piramida, 2015. - 342 s. - Bibliohr. : s. 298-340.

12. Surmin Yu. P. Maisternia vchenoho: Pidruchnyk dlia naukovtsia. - K.: Navchalno-metodychnyi tsentr "Konsortsium z udoskonalennia menedzhment-osvity v Ukraini", 2006. - $302 \mathrm{~s}$.

13. Yahupov V. V. Modeliuvannia navchalnoho protsesu yak pedahohichna problema / V. V. Yahupov // Neperervna profesiina osvita: teoriia i praktyka : nauk. metod. zhurn. / [holov. red. S. Sysoieva]. - K., 2003. - Vyp. 1. - S. 28-36.

14. Yahupov V. V. Sub'iektnist uchniv yak osnovna determinanta dystantsiinoho navchannia v systemi profesiino-tekhnichnoi osvity / V. V. Yahupov // Nauk. visnyk In-tu prof.-tekh. osvity NAPN Ukrainy. Profesiina pedahohika : zb. nauk. prats : Vyp. 11 / Inst-t prof.-tekh. osvity NAPN Ukrainy ; [Red. kol. V. O. Radkevych (holova) ta in.]. - K. : Milenium, 2016. - S. 29-37.

Одержано статтю: 1.02 .2019

Прийнято до друку: 22.02.2019

УДК $378.004 .12: 378: 378.126: 378.22$

DOI: $10.15330 /$ esu. $15.96-104$

\section{Галина Михайлишин,}

доктор філософських наук, професор, ДВНЗ "Прикарпатський національний університет імені Василя Стефаника" (м.Івано-Франківськ, Україна)

Galyna Mykhaylyshyn, Doctor of philosophical science, Professor, Vasyl Stefanyk Precarpathian national university (Ivano-Frankivsk, Ukraine) galmuh60@gmail.com

\section{Оксана Кондур,}

кандидат фізико-математичних наук, доцент, ДВНЗ "Прикарпатський національний університет імені Василя Стефаника" (м.Івано-Франківськ, Україна)

\section{Oksana Kondur,}

Candidate of physics and mathematics scie nces, Associate Professor, Vasyl Stefanyk Precarpathian National university (Ivano-Frankivsk, Ukraine) oxikon13@gmail.com

\section{ПЕДАГОГІЧНЕ МОДЕЛЮВАННЯ ПРОФЕСІЙНОЇ ПЦДГОТОВКИ УПРАВЛІНЦВ} 3 ЯКОСТІ ОСВІТИ

\section{THE PEDAGOGICAL MODELING OF PROFESSIONAL TRAINING OF MANAGERS FROM QUALITY OF EDUCATION}

Освітня глобалізачія зумовила модернізачію украйнськой освітньо-наукової системи вищої освіти. 3 метою забезпечення ї ефективності розроблено структурноорганізаційну модель їрофесійної підготовки майбутніх управлінџів з якості освіти у 